\title{
The Implementation of Literacy Strategies in Teaching English by the English Teacher at MAN Insan Cendekia Padang Pariaman
}

\author{
Khairuddiniyah \\ Universitas Negeri Surabaya \\ Khairuddiniyahkhairuddiniyah@mhs.unesa.ac.id
}

\begin{abstract}
The global life requires the necessity to read well enough to be able to function sufficiently in this changing global population. The students have to be able to access to read for a particular purpose and to literacy, create and apply what they read and write comprehensively and applicable to the real world. For that reason, it is important to develop EFL teaching system appropriately to develop students' literacy competency. Therefore, this paper explores a study of the implementing literacy strategies by English teacher at MAN Insan Cendekia Padang Pariaman, Sumatera Barat, Indonesia. Through classroom observation, interview, and documentation- based surveys submitted to the process of implementing literacy strategies in teaching English in the classroom by the English teacher, the results revealed that the use of literacy strategies by EFL teacher in MAN IC PAPAR has no exposure to the specific how to implement literacy strategies in teaching. This will lead to the need for the establishment of standard of implementation of literacy strategies to ensure the achievement of goal of teaching English in Islamic boarding school. This paper suggests that related to the aspect to be covered in standards, namely (1) promoting literacy as well content learning (2) the text, and (3) learning situation.
\end{abstract}

Keywords—teaching English; literacy; literacy strategies

\section{INTRODUCTION}

Since the enactment of Law no 20 years 2003, the objective of the national education system is to increase the quality, relevancy, and efficiency of education management in order to face domestic and global lives. The global life requires the necessity to read well enough to be able to function sufficiently in this changing global population. The Ministry of National Education (MONE), to respond to this Law, the Indonesian government has promoted literacy movement (GSL) and released literacy movement (GLS) module as the guide in implementing literacy movement. There are three stages to get the better result. Applying literacy is a complex matter because in this part the teacher should prepare the appropriate strategy, create classroom atmosphere, and make an assessment to find learners' literacy skill.

Insan Cendekia as a popular school of The Ministry of Religious Affair at Padang Pariaman has a special interest in implementing literacy, as it relates to MAN IC's vision, i.e, balancing between knowledge, technology, and religion. The vice principle of MAN IC stated that accomplishing literacy in education process will give Insan Cendekia's students the capability to access science, technology, and rule of law, as well as using the cultural wealth and mass media. Nevertheless, he admitted that it has not run well yet and the teachers are still on process to find the appropriate concept in implementing literacy in their classroom. He also stated that very few teachers have exposure to the specific about how to implement literacy strategies in teaching.

Besides that, the process of implementing literacy strategies in teaching English will not flow smoothly; many challenges will fade the target [1]. In this case, this study emerged from an interest in understanding the processes of literacy strategies that applied by the English teacher in implementing literacy strategies in teaching, in order that this knowledge might inform effectual implementation of existing and future implementation of literacy strategies in MAN Insan Cendekia and other similar contexts. In this study, the research question is "What are the difficulties faced by the English teacher in implementing literacy strategy at MAN Insan Cendekia Padang Pariaman?"

\section{LITERATURE REVIEW}

\section{A. English Education and Literacy}

Literacy is the central of education [2]. They argue that reading and writing competence is the key to the education process. They also believe the function of literacy in formal education represent two kinds of common sense as the symbol of modernisms and as the symbol of educated person. This idea supported by ref [3] literacy today is kind of complex skill that supports daily living activity.

\section{B. Definition of Literacy}

Reference [4] define that literacy is kinds of interactions with other people in social aspect and this process is necessary as part of the literacy puzzle. They also mention that literacy is not only reading and writing, though there are other aspects of literacy development is the complex need. 
Furthermore, literacy usually covers other language skills such as listening and speaking, as well as a range of other skills including the interpretation of visual material [5].

\section{Efective Way to Teach Literacy}

To be an effective teacher in implementing literacy based on Beyond the Blueprint: Literacy in grade 4-12 and Across the Content published by Connecticut State Department of Education as in ref [6], the teacher should fulfil several characteristics. Firstly, the teacher understands the reader and writers' characteristic. Secondly, the English teacher comprehends that the text's feature. Thirdly, the English teacher understands her role in creating supportive literacy learning environment. Fourthly, the teacher understands how to teach the significant aspects of literacy. Fifthly, the effective English teacher knows how to integrate a wide variety of material in their instruction. Finally, the effective teacher comprehends how to raise student's motivation to read and write text independently.

\section{METHOD}

Qualitative approach is used in this study. Qualitative research tends to use words or pictures rather than statistics to describe the central phenomenon under the research [7]. Moreover, this study was also a case study since MAN IC only had one English teacher and case study was not proposed to infer the result of the description of the certain larger population. The result might be specific and particular to subject under study [7]. In this study, the researcher used some research instruments to obtain the detail information and data. Based on research design was stated as qualitative research, the researcher chosen three techniques; observation, interview, and documentation.

\section{RESULT}

The literacy strategies implementation's data in the class were gained from class observation, teacher interview, and document. In the document, the researcher highlighted two kinds of literacy strategies were applied in the teaching process, QAR, and graphic thinking organizer. However, the observation data showed a very different reality from the survey data. There were three kinds of literacy strategies were applied, they were QAR, graphic thinking organizer, and walk this way-talk this way-look this way.

Related to interview data found "Honestly, I don't have a clear concept what literacy is (Line 5). "Reading strategies and literacy is not quite any different" (Line 6). "GLS module was not 'teacher friendly' (unstructured interview, 2017); She further said "Me myself I have to learn a lot about literacy and also the strategies that's why I asked your research materials so I can have a better understanding of what literacy are. The schoolis beyond my expetation, physical and nonphysical facilities such as varyietiesbook alsointernet access are provided, so I do not have to go to the downtown to search internet access, training or workshop about literacy"(Line 7.8).
Based on the table 4.4 this seemed to indicate she had the basic knowledge of the literacy strategies. Whilst the researcher tried to question her about what has meant by the literacy content learning-the reader, the text, and learning situation-interact to build text comprehend, she was able to explain that the text suitable with students' level, characteristics, background knowledge, vocabulary mastery, and linguistic complexity. She admitted that that aspect was part of knowledge that influence of implementing literacy strategies. TABLE I is the result of observation and interview data which showed by teacher in implementing literacy strategies.

TABLE I. WHAT THE TEACHER KNOW AND ARE ABLE TO DO IN APPLYING LITERACY STRATEGIES

\begin{tabular}{|c|c|}
\hline The Basic Principles Teacher Should Know & Checklist \\
\hline $\begin{array}{l}\text { 1. Effective teachers understand reader and writer } \\
\text { characteristic. }\end{array}$ & $\sqrt{ }$ \\
\hline $\begin{array}{l}\text { 2. Effective teacher comprehend the texts' feature to be } \\
\text { selected to support content learning, including technology, } \\
\text { as well as conventional print resources. }\end{array}$ & $\sqrt{ }$ \\
\hline $\begin{array}{l}\text { 3. Effective teachers understand their role in creating learning } \\
\text { context and a supportive literacy-learning environment. }\end{array}$ & $\sqrt{ }$ \\
\hline $\begin{array}{l}\text { 4. Effective teachers understand how to teach significant } \\
\text { aspects of literacy to a wide range of students through } \\
\text { reading and writing process. } \\
\text { The teacher understands her role as effective model, } \\
\text { teaching and building scaffold comprehension strategies in } \\
\text { reading, writing, listening, speaking, viewing and } \\
\text { presenting. } \\
\text { - The teacher knows how to teach important vocabulary. } \\
\text { - The teacher canbuild student's accurate, fluent word } \\
\text { identification in context } \\
\text { - The teacher teachs the students writing effectually. }\end{array}$ & $\begin{array}{l}\sqrt{ } \\
\sqrt{ } \\
\sqrt{ }\end{array}$ \\
\hline $\begin{array}{l}\text { 5. Effective teachers know how to integrate a wide variety of } \\
\text { materials in their instruction. }\end{array}$ & $\sqrt{ }$ \\
\hline $\begin{array}{l}\text { 6. Effective teachers raise motivation to read and write } \\
\text { independently. }\end{array}$ & $\sqrt{ }$ \\
\hline
\end{tabular}

\section{DISCUSSION}

The literacy movement was promoted in 2015 and the notion of literacy movement module (GSL) launched in 2016 was understood differently on the ground. The English teacher articulated her view in a different way in applying literacy strategies in teaching as the last stage in implementing literacy strategies. Based on the interview, document and classroom observation, it seemed that the English teacher found it difficult to understand the literacy strategies, particularly in implementing it in class. She was able to define literally literacy strategies implicit.

Regarding to interview data the teacher cannot judge literacy strategies is not quite different with reading strategies. In ref [6] stated that the instructional strategies provided for the teacher to support their students' literacy competence and reading strategies are used by students to understand the text and become an efficient readers as in ref [9]. Therefore, the teacher must understand and apply the instructional strategies of literacy appropriately, because the link between strategic teaching and student learning is the keystone of the professional development plan [10]. 


\section{CONCLUSION AND SUGGESTIONS}

The researcher summated it up as assured in the previous passage, the teacher has the prior knowledge about literacy, component, and principles to apply it in the classroom, however, teacher's teaching experiences and familiarity with the literacy strategies is low. In this case, as admitted by the teacher in the interview she was lack of knowledge, workshop, and training about literacy implementation in the classroom. Therefore, the school or institution and the government must develop it gradually; to increase the EFL teacher competency in literacy strategies, so the teacher can promote literacy as well content learning, the text' characteristics, and learning situation. And the major barrier faced by the teacher of MAN IC PAPAR about the lack of knowledge of literacy implementation inside the classroom will be accomplished. Then, the barriers of facilities support must cover the school actively by providing the fitting facilities to support literacy movement inside or outside the classroom to support the government's policy.

\section{References}

[1] Howe, "Louisiana teacher familiarity, usefulness and recommendation of content literacy strategies." in AABRI Journal. vol. 4, 2012, pp.1-10.

[2] M. Kalantzis and C. Bill, Multiliteracies Literacy Learning and the Design of Social Future. London: Rutledge, 2000.

[3] K. Pahl and R. Jennifer, Literacy and Education. London: Paul Chapman Publishing, 2005.

[4] E. Keefe and C. Susan, Literacy Strategy for all Students: Accessing the General Education Curriculum. USA: The PEAL Center, 2015.

[5] M. Lemos, "Closing the Gap between Research and Practice: Foundation for the Acquisition of Literacy." in Australia: ACER, 2007.

[6] Connecticut State Departement of Education. Beyond the Blueprint: Literacy in grade 4-12 and Across the Content. USA: Connecticut University, 2007.

[7] J.W. Cresswell, Educational research: planning: conducting and evaluating quantitative and qualitative research (fourth ed). Boston: Pearson education Inc, 2012.

[8] Brown, Abbie. H, and Timothy D. Green. (2016). The Essential of Instructional Design (Connecting Fundamental Principles wirh Process and Practice $3^{\text {rd }}$ Edition). New York: Routledge

[9] A. H. Brown, and D.G. Timothy, The Essential of Instructional Design (Connecting Fundamental Principles wirh Process and Practice $3^{\text {rd }}$ Edition). New York: Routledge, 2016.

[10] D. Fisher, F. Nancy, and W. Douglas, "Seven Literacy Strategies That Work." in Educational Leadership Journal, 2002. vol.60. p.72. 